\title{
The GM-BP Neural Network Prediction Model for International Competitiveness of Computer Information Service Industry
}

\author{
Xianhang Xu ${ }^{1,2, * \mathbb{C}}$, Mohd Anuar Arshad ${ }^{2, *}$, Ubaid Ali ${ }^{2,3}$ and Arshad Mahmood ${ }^{4}$ \\ 1 School of Innovation and Entrepreneurship, Chongqing Institute of Engineering, Chongqing 400056, China \\ 2 School of Management, Universiti Sains Malaysia, Gelugor 11800, Malaysia; Ubaid@cuiatd.edu.pk \\ 3 Management Sciences Department, COMSATS University Islamabad, Abbottabad 22010, Pakistan \\ 4 School of Business and Economics, University of Wuppertal, 42119 Wuppertal, Germany; arshad@usm.my \\ * Correspondence: xuxianhang@cqie.edu.cn (X.X.); anuar_arshad@usm.my (M.A.A.)
}

Citation: Xu, X.; Arshad, M.A.; Ali, U.; Mahmood, A. The GM-BP Neural Network Prediction Model for International Competitiveness of Computer Information Service Industry. Algorithms 2021, 14, 308. https://doi.org/10.3390/a14110308

Academic Editors: Frank Werner and Jie Zhang

Received: 12 September 2021

Accepted: 22 October 2021

Published: 23 October 2021

Publisher's Note: MDPI stays neutral with regard to jurisdictional claims in published maps and institutional affiliations.

Copyright: (c) 2021 by the authors. Licensee MDPI, Basel, Switzerland. This article is an open access article distributed under the terms and conditions of the Creative Commons Attribution (CC BY) license (https:/ / creativecommons.org/licenses/by/ $4.0 /)$.
Abstract: The computer information service industry is closely related to the fourth industrial revolution and stands at the core of the global value chain. It has become an essential engine for developing industries in various countries, and its scale is constantly expanding. In the critical period of global economic transformation and development, the use of mathematical models to predict its international competitiveness will help scientifically evaluate the development level of the industry and accelerate the adaptation to the needs of the fourth industrial revolution. In this article, a prediction model is proposed for the international competitiveness of the computer information service industry. First, we used the Revealed Comparative Advantage (RCA) index to measure the international competitiveness of the computer information service industry. Furthermore, based on the characteristics of the industry and high-quality development theory, we constructed the evaluation indicator system of influencing factors and used the grey relational analysis method to screen key indicators. Then, we combined the Grey model and BP neural network algorithm to construct the GM-BP prediction model. Finally, China is used as an example to predict the international competitiveness of its computer information service industry, and suggestions are made for industrial development. The results show that the grey relational analysis method can genuinely reflect the impact of different aspects on the international competitiveness of China's computer information service industry and better determine the key indicators of influencing factors. The GM-BP model has minor errors and excellent simulation results and can accurately predict the future status of international competitiveness. The applicability and reliability of the model are reasonable.

Keywords: computer information service industry; international competitiveness; BP neural network; grey relational degree; high-quality development

\section{Introduction}

In the era of the service economy, service trade has become the core driving force to promote global business development. The computer information service industry is most closely associated with the fourth industrial revolution among all the service trade industries and stands at the core of the global value chain. It has become the engine of industrial development, and its scale is expanding rapidly. As shown in Figure 1, the world's computer information service exports have been on a growth trend from 2010 to 2019. The export value has risen from 320.97 billion U.S. dollars to 678.22 billion U.S. dollars, an increase of 1.11 times in 10 years, with an average growth rate of about $8.65 \%$ per year, 1.72 times that of world service trade in the same period. The industry is developing very fast and has attracted more and more scholars' attention. Therefore, in the critical period of global economic transformation and development, it is of immense importance to analyze the factors that affect the computer information service industry's international competitiveness and build a prediction model from the perspective of highquality development. It helps to adapt to the needs of the global economic servicing and 
the fourth industrial revolution and provides suggestions for accelerating the development of the industry.

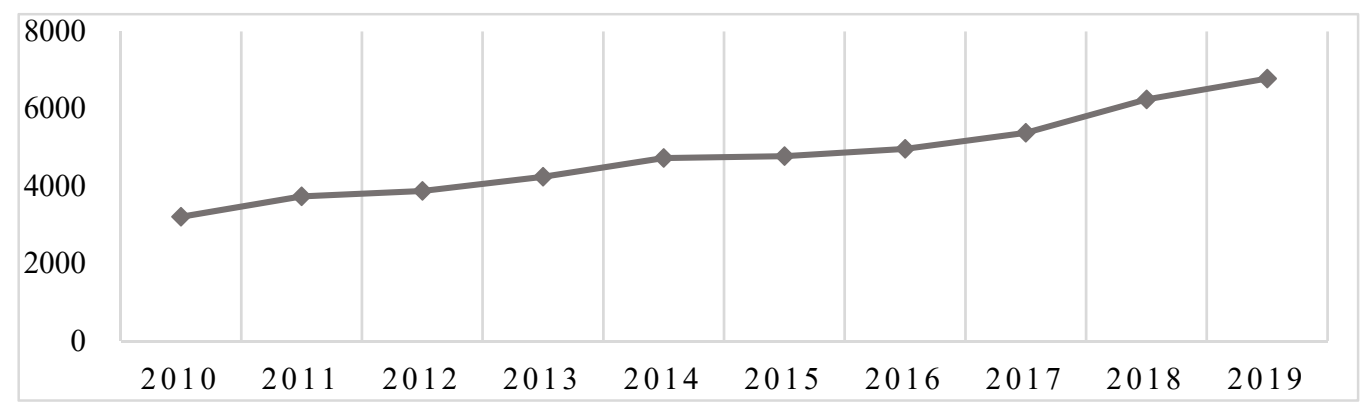

Figure 1. World export of computer information services (Unit: 100 million U.S. dollars). Source: the official websites of WTO.

This study aims to further enrich the results of the international competitiveness of the computer information service industry by constructing an optimization model that is more in line with the characteristics of the industry, especially the related research on the prediction of the international competitiveness of the industry. The research includes the following objectives: (1) To use the grey relational analysis method to determine the key indicators affecting the international competitiveness of computer information service industry; (2) To develop an optimization model for predicting the international competitiveness of computer information service industry. The main contribution of this paper is to combine Grey theory and BP neural network algorithm to propose a GM-BP neural network model that can predict the international competitiveness of the computer information service industry. The model we have proposed has minor errors and excellent simulation results.

The rest of this article is organized as follows. Section 2 briefly reviews the scholars' studies on the international competitiveness of the computer information service industry. Section 3 presents the GM-BP neural network prediction model. Section 4 validates and predicts the international competitiveness of China's computer information service industry based on the proposed method. Finally, there are discussions (Section 5) and conclusions (Section 6).

\section{Literature Review}

In the previous study, Balassa [1] and Porter [2] first proposed using the Revealed Comparative Advantage Index (abbreviated as RCA index) and diamond model to analyze the international competitiveness of the industry. After that, scholars began to study the international competitiveness of different industries with the help of various evaluation indexes and econometric models [3-8]. Scholars' studies have continuously improved the theoretical system of international competitiveness. However, there are few results on the international competitiveness of computer information service industry at present. These studies mainly include the following two categories.

The first category is to measure the industry's international competitiveness with the help of various evaluation indexes. For instance, Grimm [9] used import and export data to evaluate the trade structure and international competitiveness of computer information services in the United States and used the model to predict the trade potential of cooperating countries. In addition, Biryukova and Matiukhina [10] analyzed the international competitiveness of computer information service trade of BRIC (Brazil, Russia, India, and China) countries with the help of the RCA index and put forward suggestions for internal cooperation. They suggested that the scientific and technological cooperation of the BRIC countries in the field of ICT service trade should be included in the national policy priority list, and the research results should be further commercialized. Further, with the help of TC, RCA, and NRCA indexes, Wang [11] evaluated the international competitiveness 
of computer information service trade between China and ASEAN countries and put forward some suggestions from the aspects of strengthening infrastructure construction and promoting differentiated cooperation.

The second category is to study the factors that affect the industry's international competitiveness from qualitative and quantitative perspectives. Liang and Liu [12] followed this perspective by using the diamond model to conduct an empirical study on the factors affecting the international competitiveness of computer information service trade among China, Japan, and Korea. The result showed that domestic market demand and trade openness were the two most important factors influencing the three countries. Besides that, Guo [13] constructed a regression model based on diamond theory to analyze the influence of different indicators on the international competitiveness of China's computer information service trade. The analysis result showed that knowledge resources and demand levels were the main influencing factors, and human resources were additional factors. Guo recommended increasing investment in $R \& D$ and education, accelerating the training of industrial talents, and learning from other countries' advanced experience. Further, Li and Fan [14] used the co-integration equation to make an empirical analysis of the factors affecting the international competitiveness of China's ICT industry from the aspects of competitive strength, competitive potential, and competitive environment. This analysis revealed that technological innovation factors have the most significant positive impact on the international competitiveness of the ICT industry, and the number of companies and foreign direct investment have adverse effects on the international competitiveness of the ICT industry to varying degrees. In addition, Nath and Liu [15] empirically analyzed the impact of the development of the computer information service industry and other service trade industries on their international competitiveness with the help of panel data from 49 countries. Their study revealed that ICT significantly impacts financial services, insurance services, other commercial services, royalties and license fees, transportation, and travel. Wang and Chen [16] qualitatively analyzed the factors affecting China's computer information service industry of international competitiveness from government support, enterprise-scale and management level, park construction, and industry association. The conclusion from this study suggests that the industry's international competitiveness should be strengthened from three aspects: government, enterprises, and industry associations. The government should rationally guide the development of the industry, enterprises should expand the scale of the industry and improve the level of operation and management, and industry associations should provide first-hand international market information.

Some scholars began to shift from status evaluation to trend prediction in recent years while studying international competitiveness. Based on the influencing factors, Zhang and Xue [17] predicted the international competitiveness of China's manufacturing industry by using an error correction model, generalized impulse response, and prediction variance decomposition test. Tang et al. [18] used GM $(1,1)$ model to predict China's manufacturing industry's development quality and international competitiveness. The prediction results showed that the international competitiveness of China's manufacturing industry presented a relatively apparent "strong-weak-strong" M-shaped slight fluctuation trend, which was easily affected by the external economic environment. Zhao and Yang [19], based on the trade data of grass seeds from 2008 to 2019, predicted the export competitiveness of Chinese grass seeds by using the H-P filtering method and ARIMA model. Jiang and Xiong [20] combined neural network and fuzzy system theory to establish a forecasting model of national export competitiveness. The results showed that the use of the EMNN model showed a reasonable degree of fit to the export forecast, and the error was far less than $1 \%$, indicating that the prediction model is reasonable and feasible. Based on the analysis of factors affecting the international competitiveness of Russian forest products, $\mathrm{Li}$ and Zhang [21] predicted the export volume of Russia's main forest products before 2030.

Through literature review, we found that the current studies on the international competitiveness of the computer information service industry have the following problems. 
First, the analysis of the indicator system of influencing factors is not comprehensive enough, and the combination with the industry characteristics and new development concept is insufficient. Second, scholars primarily measure and compare the current situation of international competitiveness based on the index system and lack relevant research on the prediction of future competitiveness.

\section{Construction of GM-BP Prediction Model}

GM-BP neural network model is the combination of Grey theory and BP neural network [22]. Grey theory can predict the system with uncertain factors. Its core content is to establish grey dynamic models and transform time series into dynamic equations. This method has been widely used in various prediction fields [23]. BP neural network is one of the most widely used neural networks at present. It adopts the error back propagation algorithm and has no hierarchical interconnection structure within the layer without feedback. It has good dynamic simulation capabilities, self-learning, and selforganization capabilities and is used in scientific predictions. It has unique advantages and can better deal with uncertainty, multiple factors, and complex nonlinear mapping in predicting industrial competitiveness [24]. The GM-BP neural network model constructed in this paper is expected to the advantages of the two theories. Compared with the single Grey prediction model or BP neural network, the prediction efficiency is more guaranteed. Because of this, this article first measures the international competitiveness of the computer information service industry with the aid of the RCA index. Then, we combine the characteristics of the industry and the concept of high-quality development to construct an evaluation indicator system for factors affecting international competitiveness, and use the grey relational analysis method to screen key indicators. Finally, combining Grey theory and BP neural network theory, a GM-BP neural network prediction model is established to predict the international competitiveness of the computer information service industry.

\subsection{Competitiveness Evaluation}

When scholars evaluate the international competitiveness of industries, most of them use trade performance indexes to measure competitiveness. This method mainly uses import and export trade data for measurement. It is relatively intuitive and can also reflect the actual level of international competitiveness. Therefore, this paper uses the commonly used RCA index for comparison. The calculation equation of RCA is as follows:

$$
\operatorname{RCA}_{\mathrm{ij}}=\frac{\mathrm{M}_{\mathrm{ij}}}{\mathrm{S}_{\mathrm{ij}}} \div \frac{\mathrm{M}_{\mathrm{wj}}}{\mathrm{S}_{\mathrm{wj}}}
$$

Here, $M_{i j}$ represents the export of computer information services in country $i, S_{i j}$ represents the total service exports of country $i, M_{w j}$ represents the world export of computer information services, and $S_{\mathrm{wj}}$ represents the world's total exports of services.

\subsection{Key Indicators Selection}

\subsubsection{Analysis Framework}

Since many scholars have verified the universal applicability and reasonable explanation of the diamond model [25-29], to determine the analysis framework of influencing factors of industrial competitiveness, this paper improves the diamond model with the idea of "retention + supplement". Among the six elements of the diamond model, corporate organizational strategy and competition elements are affected by multiple factors such as industry, time, and space. It is difficult to analyze from the source. The government behavior elements themselves are difficult to quantify and lack coherence from the perspective of time series. Therefore, this paper retains the four elements: production, demand, conditions related to supporting industries, and external opportunities. Combining the industrial high-quality development concept of "innovation, coordination, green, openness, 
and sharing" and the knowledge-intensive characteristics of the computer information service industry, these supplement the elements of innovation and technological development. Finally, an analysis framework is constructed from five dimensions: innovative development, coordinated development, green development, open development, and shared development.

\section{(1) Innovative development}

Corresponding to the innovation and technological development elements, mainly from driving force formation, it examines the driving effect of R\&D investment, intellectual property rights, technological level, and innovation environment on industrial competitiveness.

\section{(2) Coordinated development}

Corresponding to relevant supporting industry elements, mainly from the industrial association and industrial synergy, tangible and intangible goods are complementary and supporting industries. The impact of related industries and supporting industries on industrial competitiveness is examined.

\section{(3) Green development}

Corresponding to the production elements, the sustainable development of the industry is emphasized. Since the computer information service industry is an innovative and lowcarbon industry, it depends less on ecological environment resources. It mainly examines the impact of human resources, capital, and other resource elements on industrial competitiveness.

(4) Open development

Corresponding to the external opportunities elements, it reflects the impact of a country's level of globalization on the international competitiveness of industries. It mainly starts from participating in global economic governance and examines globalization and external opportunities on industrial competitiveness.

\section{(5) Shared development}

Corresponding to the demand condition elements, it reflects the relationship between economic development and the industry, mainly from realizing the sharing of development results by the people and examining the impact of per capita economic level on industrial competitiveness.

Based on the above analysis, drawing on the scholars' selection of indicators when evaluating the international competitiveness and high-quality development of the industry [30-33], and considering the representativeness and availability of data, 14 indicators are finally selected to construct the evaluation system of influencing factors of the international competitiveness of the industry, as shown in Table 1.

Table 1. Evaluation system of influencing factors of international competitiveness.

\begin{tabular}{|c|c|c|c|}
\hline Level I & Level II & Unit & The Data Source \\
\hline \multirow{4}{*}{ Innovation development } & R\&D investment intensity $\left(X_{1}\right)$ & $\%$ & China Statistical Yearbook \\
\hline & $\begin{array}{l}\text { Number of patent applications in computer } \\
\text { communication industry }\left(X_{2}\right)\end{array}$ & 10,000 pieces & China Statistical Yearbook \\
\hline & R\&D investment in computer communication industry $\left(X_{3}\right)$ & 10 billion RMB Yuan & China Statistical Yearbook \\
\hline & Global Innovation Index $\left(\mathrm{X}_{4}\right)$ & l & WIPO official website \\
\hline \multirow{3}{*}{ Coordinated development } & Export of other services $\left(X_{5}\right)$ & 10 billion U.S. dollars & WTO official website \\
\hline & Exports of goods $\left(\mathrm{X}_{6}\right)$ & 10 billion U.S. dollars & WTO official website \\
\hline & Proportion of manufacturing value-added to GDP $\left(X_{7}\right)$ & $\%$ & China Statistical Yearbook \\
\hline \multirow{2}{*}{ Green development } & Proportion of college students in total number $\left(\mathrm{X}_{8}\right)$ & $\%$ & China Statistical Yearbook \\
\hline & Foreign capital utilized $\left(X_{9}\right)$ & 10 billion U.S. dollars & China Statistical Yearbook \\
\hline \multirow{3}{*}{ Open development } & Globalization index $\left(\mathrm{X}_{10}\right)$ & / & KOF official website \\
\hline & Openness to trade in services $\left(X_{11}\right)$ & $\%$ & WTO official website \\
\hline & Annual exchange rate of USD to RMB $\left(\mathrm{X}_{12}\right)$ & Yuan & China Statistical Yearbook \\
\hline \multirow{2}{*}{ Shared development } & GDP per capita $\left(X_{13}\right)$ & 10,000 RMB Yuan & China Statistical Yearbook \\
\hline & Per capita GDP growth rate $\left(\mathrm{X}_{14}\right)$ & $\%$ & China Statistical Yearbook \\
\hline
\end{tabular}




\subsubsection{Key Indicators Selection}

In order to analyze the degree of influence of various factors, it is necessary to carry out a quantitative measurement with the aid of a measurement model. At present, the typical analysis methods include factor analysis, PCA analysis, AHP analysis, VAR model analysis, and grey correlation analysis [34-37]. This paper measures the correlation degree between different influencing factors and the RCA index by the grey correlation analysis method and determines the key indicators based on the correlation degree.

Step 1: Determine the reference sequence, $X_{0}=\left\{X_{0}(1), X_{0}(2), \cdots, X_{0}(n)\right\}$. This paper takes the RCA index value of China's computer information service trade from 2010 to 2019 as the reference series.

Step 2: Select the comparison sequence, $X_{i}=\left\{X_{i}(1), X_{i}(2), \cdots, X_{i}(n)\right\}$. In this paper, the data of 2010-2019 of all secondary indicators in Table 1 are taken as the comparison sequence.

Step 3: Raw data processing. The buffer operator is weakened by geometric average to eliminate the influence of interference factors.

$$
X(k) d=\left[x_{i}(k) \cdot x_{i}(k+1) \cdots \cdot x_{i}(n)\right]^{\frac{1}{n-k+1}}
$$

Step 4: Use the mean value method to conduct dimensionless data processing to eliminate the dimensional influence.

$$
X_{i}^{\prime}(t)=X(k) d / \overline{X(k) d}
$$

Step 5: Calculate the correlation coefficient.

$$
\delta\left(X_{0}^{\prime}(t), X_{i}^{\prime}(t)\right)=\frac{\min _{i} \min _{t}\left|X_{0}^{\prime}(t)-X_{i}^{\prime}(t)\right|+\rho \max _{i} \max _{t}\left|X_{0}^{\prime}(t)-X_{i}^{\prime}(t)\right|}{\left|X_{0}^{\prime}(t)-X_{i}^{\prime}(t)\right|+\rho \max _{i} \max _{t}\left|X_{0}^{\prime}(t)-X_{i}^{\prime}(t)\right|}
$$

Step 6: Calculate the correlation.

$$
\gamma\left(\mathrm{X}_{0}^{\prime}(\mathrm{t}), \mathrm{X}_{\mathrm{i}}^{\prime}(\mathrm{t})\right)=\frac{1}{\mathrm{n}} \sum_{\mathrm{i}=1}^{\mathrm{n}} \delta\left(\mathrm{X}_{0}^{\prime}(\mathrm{t}), \mathrm{X}_{\mathrm{i}}^{\prime}(\mathrm{t})\right)
$$

Step 7: Key indicators selection.

According to the grey system theory, the larger the indicator correlation degree, the greater the influence. When $\rho=0.5$, if the correlation degree is greater than 0.6 , there is a significant influence. Therefore, we identify indicators with a correlation degree greater than 0.6 as key indicators.

\subsection{Prediction of Key Indicators}

By constructing GM $(1,1)$ grey prediction model, the predicted values of key indicators are calculated. The calculation steps are as follows:

Step 1: Use $X^{(0)}(k)$ to represent the original data sequence of key indicators and set the original data.

$$
X^{(0)}(k)=\left\{X^{(0)}(1), X^{(0)}(2), \cdots, X^{(0)}(n)\right\}
$$

Step 2: Perform a cumulative generation algorithm for $X^{(0)}(k)$ to generate a first-order cumulative generated number sequence.

$$
X^{(1)}(k)=\left\{X^{(1)}(1), X^{(1)}(2), \cdots, X^{(1)}(n)\right\}
$$


Step 3: According to Equation (7), the series $Z^{(1)}$ adjacent to the mean value of $X^{(1)}(k)$ is calculated. $Z^{(1)}(k)=\left\{Z^{(1)}(1), Z^{(1)}(2), \cdots, Z^{(1)} n\right\}$. Here:

$$
\mathrm{Z}^{(1)}(\mathrm{k})=\frac{1}{2}\left(\mathrm{X}^{(1)}(\mathrm{k})+\mathrm{X}^{(1)}(\mathrm{k}-1)\right), \mathrm{k}=2,3, \cdots, \mathrm{n}
$$

Step 4: Construct the differential equation $d x^{(1)} / d t+\alpha x^{(1)}=\beta$. Here, the parameters $\alpha$ and $\beta$ can be obtained by the following equations:

$$
[\alpha, \beta]^{\mathrm{T}}=\left(\mathrm{B}^{\mathrm{T}} \mathrm{B}\right)^{-1} \mathrm{~B}^{\mathrm{T}} \mathrm{Y} \text {, type : } \mathrm{Y}=\left[\begin{array}{c}
X^{(0)}(2) \\
X^{(0)}(3) \\
\vdots \\
X^{(0)}(\mathrm{n})
\end{array}\right], \mathrm{B}=\left[\begin{array}{cc}
-Z^{(1)}(2) & 1 \\
-Z^{(1)}(3) & 1 \\
\vdots & \vdots \\
-Z^{(1)}(\mathrm{n}) & 1
\end{array}\right]
$$

Step 5: Solve the above differential equations to obtain the GM $(1,1)$ model.

$$
\hat{\mathrm{X}}^{(0)}(\mathrm{k}+1)=\left[\mathrm{X}^{(0)}(1)-\frac{\beta}{\alpha}\right] \exp (-\mathrm{ak})+\frac{\beta}{\alpha}(\mathrm{k}=0,1,2, \ldots, \mathrm{n})
$$

Step 6: Calculate the predicted value of $X^{(0)}(k)$.

$$
\hat{\mathrm{X}}^{(0)}(\mathrm{k}+1)=\hat{\mathrm{X}}^{(1)}(\mathrm{k}+1)-\hat{\mathrm{X}}^{1}(\mathrm{k})(\mathrm{k}=0,1,2, \ldots, \mathrm{n}-1)
$$

\subsection{Model Construction}

The industry's prediction model of international competitiveness based on GM-BP neural network mainly includes the process of quantity sample, the design of network structure, the training and inspection of the network, and the prediction of competitiveness trend.

Step 1: Data sample processing.

The extreme value method is used to normalize the data to ensure consistency.

$$
Y_{i j}=\frac{X_{i j}-\min \left(X_{i}\right)}{\max \left(X_{i}\right)-\min \left(X_{i}\right)}
$$

Here, $X_{i j}$ is the original value, $Y_{i j}$ is the normalized value, $X_{i}=\left\{X_{1}, X_{2}, \ldots, X_{j}\right\}$.

Step 2: Network structure design.

The network structure design mainly includes determining the number of network layers and setting the network nodes. The topological structure of the BP neural network model is the input layer, hidden layer, and output layer. Existing studies have proved that the performance of the three-layer BP neural network model with only one hidden layer is better than that with multiple hidden layers. When building the model, the three-layer BP structure with only one hidden layer can be established first. The number of network nodes in the input and output layers is determined by the variables selected during model construction and the number of prediction objects. The number of hidden layer nodes is essential to the neural network's performance, and the number of hidden layer nodes can be determined by empirical formulas [38].

$$
\mathrm{L}=\sqrt{\mathrm{M}+\mathrm{N}}+\mathrm{a}
$$

Here, $\mathrm{L}$ represents the number of hidden layer nodes, $\mathrm{M}$ is the number of input layer nodes, $\mathrm{N}$ is the number of output layer nodes, and a constant from 1 to 10 .

Step 3: Sample training and testing.

This model is simulated and trained by MATLAB, mainly using RPROP and Symmetrical Sigmoid functions. Among them, the network training function selects RPROP, and the transfer function of the hidden layer and the output layer selects Symmetrical Sigmoid. The RPROP algorithm is one of the most effective training algorithms for supervised feed- 
forward neural networks. Its advantage is that it does not require parameter settings before use, and there is no need to determine the learning rate, momentum value, or update constantly. The Symmetrical Sigmoid function is characterized by being anti-symmetric, zero center, and differentiable. Its flatter shape and slower descending derivation indicate that it can learn more effectively.

The collected samples are divided into two parts: one part is the training sample, and the other part is the test sample. All samples are trained and tested. The construction of the BP neural network is completed through the forward operation output of all samples and the reverse modification of weights to reduce the error until the accuracy requirements are met.

Step 4: Competitiveness prediction.

The input layer takes the grey pre-processing value of the RCA index obtained by the GM $(1,1)$ model as the input data, uses the established BP neural network model to calculate, and outputs the predicted value of the international competitiveness of China's computer information service industry.

\section{Predictive Analysis}

In 2019, China's service trade total imports and exports reached 778.618 billion U.S. dollars, ranking second in the world, but its service trade deficit was as high as 215.316 billion U.S. dollars. As the industry with the largest surplus and fastest development in China's service trade, the computer information service industry occupies an important position. From 2010 to 2019, China's computer information service imports had an overall increase from 4.103 to 26.861 billion U.S. dollars, while information service exports showed an overall upward rising from 10.476 to 53.785 billion U.S. dollars in 10 years. It shows that, in 10 years, information service imports increased 5.55 times with an average annual growth rate of $20.98 \%$, while exports increased 4.13 times with an average annual growth rate of $17.09 \%$ respectively, both much higher than the world level in the same period. Moreover, China's computer information service trade has a long-term surplus, and it tends to expand year by year. It is one of the few surplus industries in the service trade industry, and its development trend is promising. Therefore, verifying the model with China's computer information service industry as an example has good representativeness and practical significance. Hence, this article uses the RCA index to measure the international competitiveness of the computer information service industry in nine countries, including China, India, and Ireland. Then, it combines industrial characteristics and high-quality development concepts to construct an evaluation indicator system for the factors affecting the international competitiveness of the computer information service industry, and then uses grey correlation analysis to screen key indicators. Finally, combining the grey prediction model and the BP neural network algorithm, the GM-BP neural network prediction model is established to predict the international competitiveness of China's computer information service industry from 2020 to 2024.

\subsection{Comparative Analysis}

As shown in Table 2, China's computer information services total volume and export volume ranks fourth globally, and its import volume ranks third in the world. In the beginning, this study chose the top ten countries (refer to Table 2) in the total import and export volume of computer information service trade in 2019 for comparative analysis. However, data was found missing for the Netherlands. Therefore, the Netherlands was excluded and this left only nine countries: China, France, Germany, India, Ireland, Singapore, Switzerland, the United Kingdom, and the United States.

According to Equation (1), the RCA value of the computer information services trade in nine countries was calculated. Table 3 shows that, from 2010 to 2019, the RCA value of China's computer information services showed a fast-rising trend. By 2019, the RCA value had reached 1.71, indicating that the industry's international competitiveness had become very strong but far behind Ireland and India. From the comparison between 
countries, the RCA value of India and Ireland is over 2.5 all year round, indicating that the international competitiveness of their industries is extreme. The average RCA value of Germany and Switzerland is between 0.8 and 1.25, indicating that the international competitiveness of their industries is strong. The RCA values of France, Singapore, the United States, and the United Kingdom are almost all less than 0.8, indicating that the international competitiveness of their industries is weak.

Table 2. World ranking of computer information service trade in 2019 (Unit: 100 million U.S. dollars).

\begin{tabular}{cccccc}
\hline Rank & Countries & Exports & Imports & Total & Net Exports \\
\hline 1 & Ireland & 1244.41 & 57.88 & 1302.29 & 1186.53 \\
2 & United States & 556.57 & 437.20 & 993.77 & 119.37 \\
3 & Germany & 421.89 & 418.63 & 840.52 & 3.26 \\
4 & China & 537.85 & 268.61 & 806.46 & 269.24 \\
5 & India & 649.33 & 96.21 & 745.54 & 553.12 \\
6 & Netherlands & 280.82 & 187.76 & 468.58 & 93.06 \\
7 & United Kingdom & 297.25 & 133.49 & 430.74 & 163.76 \\
8 & French & 191.50 & 227.85 & 419.35 & 36.35 \\
9 & Swiss & 108.42 & 152.68 & 261.10 & 44.26 \\
10 & Singapore & 147.90 & 144.94 & 292.84 & 2.96 \\
\hline
\end{tabular}

Table 3. RCA index value of computer information services by country.

\begin{tabular}{cccccccccc}
\hline Year & China & French & Germany & India & Ireland & Singapore & Swiss & UK & USA \\
\hline 2010 & 0.72 & 0.85 & 1.15 & 4.22 & 4.97 & 0.43 & 1.07 & 0.87 & 0.57 \\
2011 & 0.82 & 0.76 & 1.13 & 4.01 & 4.90 & 0.49 & 1.01 & 0.84 & 0.55 \\
2012 & 0.94 & 0.79 & 1.19 & 3.92 & 4.64 & 0.61 & 1.10 & 0.84 & 0.59 \\
2013 & 0.94 & 0.76 & 1.16 & 4.11 & 4.73 & 0.61 & 1.11 & 0.80 & 0.59 \\
2014 & 1.01 & 0.76 & 1.08 & 3.81 & 4.67 & 0.57 & 1.29 & 0.80 & 0.57 \\
2015 & 1.22 & 0.70 & 1.14 & 3.65 & 4.40 & 0.60 & 1.28 & 0.80 & 0.57 \\
2016 & 1.29 & 0.71 & 1.23 & 3.37 & 4.41 & 0.79 & 1.21 & 0.80 & 0.57 \\
2017 & 1.24 & 0.69 & 1.25 & 2.98 & 4.31 & 0.74 & 1.12 & 0.75 & 0.60 \\
2018 & 1.66 & 0.66 & 1.20 & 2.72 & 4.60 & 0.69 & 0.98 & 0.75 & 0.56 \\
2019 & 1.71 & 0.60 & 1.13 & 2.72 & 4.67 & 0.65 & 0.81 & 0.65 & 0.58 \\
Mean & 1.16 & 0.73 & 1.17 & 3.55 & 4.63 & 0.62 & 1.10 & 0.79 & 0.58 \\
\hline
\end{tabular}

\subsection{Screening Key Indicators}

\subsubsection{Data Selection}

According to the data from the official websites of WTO, WIPO, KOF, and the China Statistical Yearbook, we have compiled the data of the influencing factors evaluation indicators in Table 1 from 2010 to 2019. The results are shown in Table 4.

Table 4. Data of influencing factors of international competitiveness of China's computer information service industry.

\begin{tabular}{ccccccccccc}
\hline & $\mathbf{2 0 1 0}$ & $\mathbf{2 0 1 1}$ & $\mathbf{2 0 1 2}$ & $\mathbf{2 0 1 3}$ & $\mathbf{2 0 1 4}$ & $\mathbf{2 0 1 5}$ & $\mathbf{2 0 1 6}$ & $\mathbf{2 0 1 7}$ & $\mathbf{2 0 1 8}$ & $\mathbf{2 0 1 9}$ \\
\hline $\mathrm{X}_{1}$ & 1.71 & 1.78 & 1.91 & 2.00 & 2.02 & 2.06 & 2.10 & 2.12 & 2.14 & 2.23 \\
$\mathrm{X}_{2}$ & 4.62 & 7.19 & 8.24 & 8.90 & 10.35 & 10.08 & 11.87 & 14.53 & 17.94 & 20.48 \\
$\mathrm{X}_{3}$ & 6.86 & 9.41 & 10.65 & 12.53 & 13.93 & 16.12 & 18.11 & 20.03 & 22.80 & 24.48 \\
$\mathrm{X}_{4}$ & 46.43 & 45.40 & 44.66 & 46.57 & 47.47 & 50.57 & 52.54 & 53.06 & 54.82 & 53.28 \\
$\mathrm{X}_{5}$ & 16.69 & 18.64 & 18.43 & 18.87 & 19.79 & 19.18 & 18.18 & 19.86 & 22.26 & 22.79 \\
$\mathrm{X}_{6}$ & 157.78 & 189.84 & 204.87 & 220.90 & 234.23 & 227.35 & 209.76 & 226.33 & 248.67 & 249.95 \\
$\mathrm{X}_{7}$ & 49.6 & 45.9 & 41.9 & 40.5 & 36.9 & 32.6 & 28.3 & 30.2 & 30.3 & 30.8 \\
$\mathrm{X}_{8}$ & 1.66 & 1.71 & 1.77 & 1.81 & 1.86 & 1.91 & 1.95 & 1.98 & 2.03 & 2.17 \\
$\mathrm{X}_{9}$ & 10.88 & 11.77 & 11.33 & 11.87 & 11.97 & 12.63 & 12.60 & 13.10 & 13.50 & 13.81 \\
$\mathrm{X}_{10}$ & 61.83 & 62.31 & 62.55 & 62.65 & 63.42 & 63.88 & 63.3 & 63.61 & 64.27 & 64.28 \\
\hline
\end{tabular}


Table 4. Cont.

\begin{tabular}{ccccccccccc}
\hline & $\mathbf{2 0 1 0}$ & $\mathbf{2 0 1 1}$ & $\mathbf{2 0 1 2}$ & $\mathbf{2 0 1 3}$ & $\mathbf{2 0 1 4}$ & $\mathbf{2 0 1 5}$ & $\mathbf{2 0 1 6}$ & $\mathbf{2 0 1 7}$ & $\mathbf{2 0 1 8}$ & $\mathbf{2 0 1 9}$ \\
\hline $\mathrm{X}_{11}$ & 6.07 & 5.92 & 5.64 & 5.59 & 6.19 & 5.88 & 5.85 & 5.60 & 5.69 & 5.43 \\
$\mathrm{X}_{12}$ & 6.77 & 6.46 & 6.31 & 6.19 & 6.14 & 6.23 & 6.64 & 6.75 & 6.62 & 6.91 \\
$\mathrm{X}_{13}$ & 3.08 & 3.63 & 3.99 & 4.37 & 4.72 & 5.02 & 5.41 & 6.00 & 6.60 & 7.09 \\
$\mathrm{X}_{14}$ & 17.68 & 17.83 & 9.84 & 9.56 & 7.99 & 6.50 & 7.77 & 10.85 & 9.98 & 7.40 \\
\hline
\end{tabular}

\subsubsection{Data Calculation}

According to Equations (2)-(5), the resolution coefficient was taken $\rho=0.5$, the correlation degree between each influencing factor and the RCA value of China's computer information service industry was calculated, and sort them. The details are as follows.

As shown in Table 5, the correlation degree between the selected influencing factors indicators and RCA value is $0.5603-0.9246$, indicating that the selected indicators have a significant correlation with China's computer information service industry's international competitiveness. The constructed model has good applicability and can truly reflect the impact of different aspects on the international competitiveness of China's computer information service industry. According to the selection requirements of key indicators, 10 indicators with a correlation degree greater than 0.6 are finally selected as key indicators.

Table 5. Grey correlation degree between the influencing factors indicators of the international competitiveness of China's computer information service industry and its RCA value.

\begin{tabular}{|c|c|c|c|}
\hline Level I & Level II & Correlation & Sorting \\
\hline \multirow{4}{*}{$\begin{array}{c}\text { Innovation } \\
\text { development }\end{array}$} & R\&D investment intensity $\left(X_{1}\right)$ & 0.7398 & 3 \\
\hline & $\begin{array}{l}\text { Number of patent applications in computer } \\
\text { communication industry }\left(X_{2}\right)\end{array}$ & 0.5982 & 12 \\
\hline & R\&D investment in computer communication industry $\left(X_{3}\right)$ & 0.6518 & 10 \\
\hline & Global Innovation Index $\left(\mathrm{X}_{4}\right)$ & 0.6892 & 7 \\
\hline \multirow{3}{*}{$\begin{array}{l}\text { Coordinated } \\
\text { development }\end{array}$} & Export of other services $\left(X_{5}\right)$ & 0.7380 & 4 \\
\hline & Exports of goods $\left(\mathrm{X}_{6}\right)$ & 0.8179 & 2 \\
\hline & Proportion of manufacturing value-added to GDP $\left(X_{7}\right)$ & 0.5961 & 13 \\
\hline \multirow{2}{*}{ Green development } & Proportion of college students in total number $\left(X_{8}\right)$ & 0.7194 & 6 \\
\hline & Foreign capital utilized $\left(X_{9}\right)$ & 0.7219 & 5 \\
\hline \multirow{3}{*}{ Open development } & Globalization index $\left(\mathrm{X}_{10}\right)$ & 0.6801 & 8 \\
\hline & Openness to trade in services $\left(X_{11}\right)$ & 0.6560 & 9 \\
\hline & Annual exchange rate of USD to RMB $\left(X_{12}\right)$ & 0.5983 & 11 \\
\hline \multirow{2}{*}{ Shared development } & GDP per capita $\left(X_{13}\right)$ & 0.9246 & 1 \\
\hline & Per capita GDP growth rate $\left(\mathrm{X}_{14}\right)$ & 0.5603 & 14 \\
\hline
\end{tabular}

\subsection{Prediction of Key Indicators}

According to Equations (6)-(12), the GM $(1,1)$ model is used to predict the future values of 10 key indicators in 2020-2024. The results are shown in Table 6.

Table 6. Predictive values of key indicators by GM $(1,1)$ model.

\begin{tabular}{|c|c|c|c|c|c|}
\hline Key Indicators & 2020 & 2021 & 2022 & 2023 & 2024 \\
\hline R\&D investment intensity $\left(Y_{1}\right)$ & 2.2286 & 2.2795 & 2.3316 & 2.3849 & 2.4394 \\
\hline $\begin{array}{c}\text { R\&D investment in computer communication } \\
\text { industry }\left(\mathrm{Y}_{2}\right)\end{array}$ & 28.3083 & 31.8386 & 35.8092 & 40.2749 & 45.2976 \\
\hline Global Innovation Index $\left(\mathrm{Y}_{3}\right)$ & 56.7702 & 58.3005 & 59.8721 & 61.4860 & 63.1435 \\
\hline Exports of other services $\left(\mathrm{Y}_{4}\right)$ & 22.3272 & 22.8853 & 23.4574 & 24.0438 & 24.6448 \\
\hline Exports of goods $\left(\mathrm{Y}_{5}\right)$ & 254.6979 & 261.5562 & 268.5992 & 275.8318 & 283.2591 \\
\hline Proportion of college students in total number $\left(\mathrm{Y}_{6}\right)$ & 2.1748 & 2.2331 & 2.2929 & 2.3544 & 2.4175 \\
\hline Foreign capital utilized $\left(\mathrm{Y}_{7}\right)$ & 14.0667 & 14.4065 & 14.7545 & 15.1108 & 15.4758 \\
\hline Globalization Index $\left(\mathrm{Y}_{8}\right)$ & 64.6077 & 64.8602 & 65.1136 & 65.3681 & 65.6235 \\
\hline Openness to trade in services $\left(\mathrm{Y}_{9}\right)$ & 5.5838 & 5.5503 & 5.5171 & 5.4840 & 5.4511 \\
\hline GDP per capita $\left(\mathrm{Y}_{10}\right)$ & 7.6964 & 8.3629 & 9.0872 & 9.8742 & 10.7293 \\
\hline
\end{tabular}




\subsection{Neural Network Model Prediction}

Firstly, the key indicators' data is normalized by Equation (12). Then, according to Equation (13), the number of hidden layer nodes is determined to be 5-14. The number of hidden layer nodes is simulated sequentially from 5 to 14, and it is found that when the number of hidden layer nodes is set to 11, the absolute percentage error is the smallest. Therefore, this paper sets the number of nodes in the hidden layer of the GM-BP neural network to 11, and the constructed network topology is shown in Figure 2.

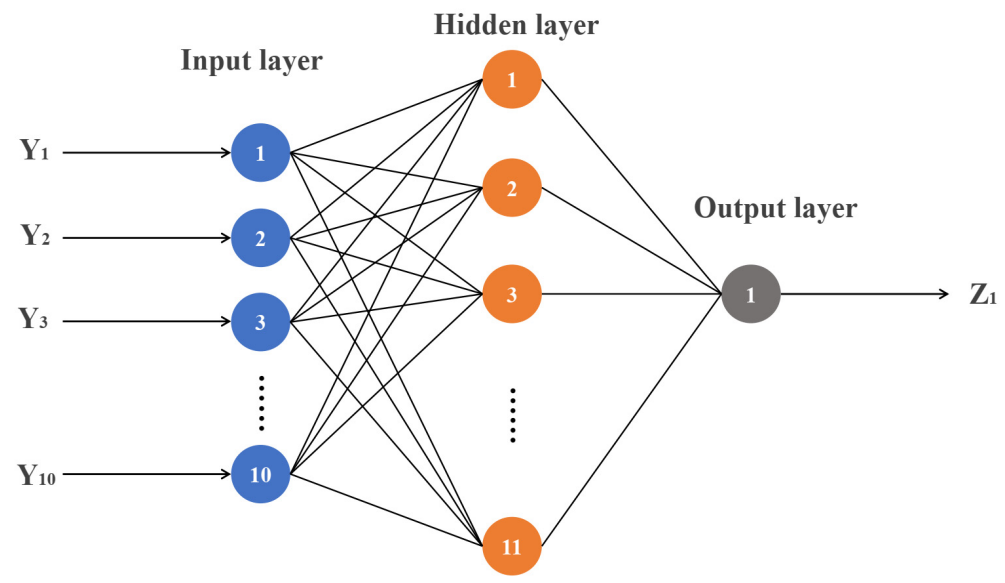

Figure 2. Network topology.

GM $(1,1)$ model and the GM-BP neural network model are used to make predictions. The input training uses the relevant data from 2010 to 2018, and the test uses the relevant data from 2019. The RCA predictive values and related errors of China's computer information service trade from 2010 to 2019 are obtained (see Table 7). As shown in Table 7, the mean absolute percentage error of the GM-BP neural network model is only $0.0553 \%$, and the prediction results in each year are closer to the actual value than the GM $(1,1)$ model. The results show that the model has high fitting accuracy and has good applicability for predicting the international competitiveness of industries.

Table 7. The predictive results of RCA value of China's computer information service industry.

\begin{tabular}{cccccc}
\hline & & \multicolumn{2}{c}{ GM (1,1) Model } & \multicolumn{2}{c}{ GM-BP Model } \\
\cline { 3 - 6 } Year & Actual Value & $\begin{array}{c}\text { Predictive } \\
\text { Value }\end{array}$ & $\begin{array}{c}\text { Absolute Percentage } \\
\text { Error (\%) }\end{array}$ & $\begin{array}{c}\text { Predictive } \\
\text { Value }\end{array}$ & $\begin{array}{c}\text { Absolute Percentage } \\
\text { Error (\%) }\end{array}$ \\
\hline 2010 & 0.7170 & 0.7170 & 0 & 0.7178 & 0.1303 \\
2011 & 0.8154 & 0.8021 & 1.6297 & 0.8150 & 0.0390 \\
2012 & 0.9440 & 0.8810 & 6.6789 & 0.9437 & 0.0040 \\
2013 & 0.9440 & 0.9675 & 2.4937 & 0.9441 & 0.0178 \\
2014 & 1.0119 & 1.0626 & 5.0144 & 1.0118 & 0 \\
2015 & 1.2230 & 1.1671 & 4.5717 & 1.2231 & 0.0262 \\
2016 & 1.2879 & 1.2818 & 0.4735 & 1.2880 & 0.0093 \\
2017 & 1.2424 & 1.4078 & 13.3122 & 1.2426 & 0.0298 \\
2018 & 1.6639 & 1.5462 & 7.0759 & 1.6643 & 0.0240 \\
2019 & 1.7079 & 1.6981 & 0.5716 & 1.6833 & 0.2723 \\
\multicolumn{2}{c}{ Mean absolute } & & 4.6468 & & 0.0553 \\
\multicolumn{2}{l}{ percentage error (\%) } & & & & \\
\hline
\end{tabular}

The GM-BP neural network prediction model is used to predict the international competitiveness of China's computer information service industry from 2020 to 2024 in combination with the predictive values of key indicators calculated in Table 6 . The predictive results are shown in Table 8 and Figure 3. According to the chart, the international 
competitiveness of China's computer information service industry will remain stable in the future, with a slowdown in growth and increasing competitive pressure.

Table 8. Predictive results of international competitiveness of China's computer information service industry.

\begin{tabular}{cccccc}
\hline Year & $\mathbf{2 0 2 0}$ & $\mathbf{2 0 2 1}$ & $\mathbf{2 0 2 2}$ & $\mathbf{2 0 2 3}$ & $\mathbf{2 0 2 4}$ \\
\hline RCA values & 1.7134 & 1.7204 & 1.7215 & 1.7183 & 1.7117 \\
\hline
\end{tabular}

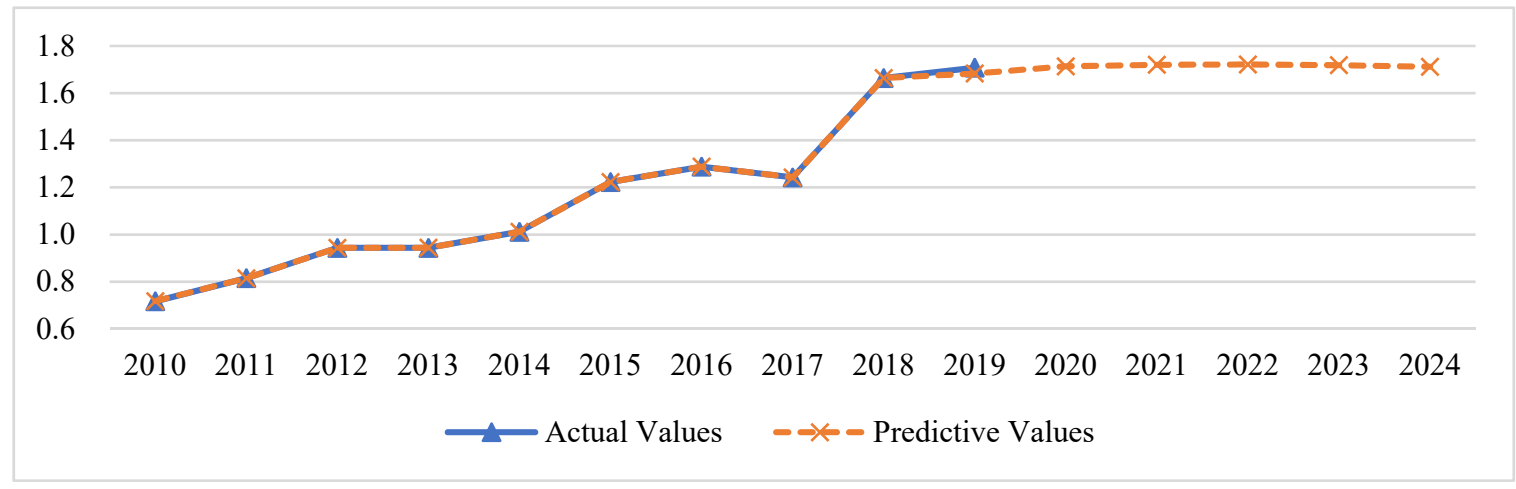

Figure 3. Actual and predictive values of international competitiveness of China's computer information service industry.

\section{Discussion}

This paper takes China's computer information service industry as an example for study. Firstly, the international competitiveness of China's computer information service industry is evaluated by the RCA index. It is found that the international competitiveness is rising year by year, and the industry is developing in a good state. However, compared with Ireland and India, there is still a large gap. Secondly, the industry international competitiveness indicator system of influencing factors is conducted from high-quality development, and the grey correlation degree analysis is carried out. Ten indicators such as GDP per capita, the export value of goods, R\&D investment intensity, and the export value of other services are significantly correlated to competitiveness. Finally, combining the Grey theory and BP neural network algorithm, a GM-BP neural network model for predicting the international competitiveness of the computer information service industry is established. Through forecasting, it is found that the future growth trend of the international competitiveness of China's computer information service industry will slow down. Through the analysis of the predictive results, the GM-BP prediction model has higher accuracy than the GM $(1,1)$ model prediction, which verifies the rationality of the prediction model established in this paper.

Through the analysis of the results, this paper further points out the direction of and recommendations for the improvement of the international competitiveness of China's computer information service industry:

(1) Deepen international cooperation and enhance the comprehensive strength of the industry. First, deepen cooperation with Ireland, India, and other countries with the help of government, international organizations, and industry associations, by introducing their advanced technology and operational management experience, accelerating the accumulation and optimization of the industry's high-end elements, and enhancing the level of the industry in the global value chain [39]. Second, seize the opportunities of global economic servitization and the fourth industrial revolution, continuously improve service quality and level following international standards, deepen relations with existing partners, and stabilize and expand the international market. At the same time, continue to expand the export of various goods and 
services to drive and promote the competitiveness of the computer information service industry. Third, encourage powerful companies in the computer information service industry to go global, seize the opportunity of China's implementation of free trade agreements with many countries, establish cooperation channels with emerging markets, and diversify export risks.

(2) Strengthen investment in innovation and stimulate internal driving forces of the industry. First, organize industry experts to focus on key technical areas, analyze technology development trends and international competitors, and guide enterprises to implement patent reserves and layout in a planned and targeted manner. At the same time, promote the integration, breakthrough, and industrialization of patented technologies, promote the upgrading of the industrial value chain and maximize the value of corporate patents. Second, use industry organizations to build patent alliances, guide enterprises to strengthen patent applications, encourage patent concentration and cross-licensing, strengthen technical barriers through patent pools, and enhance the overall competitive advantage of the industry. Third, adhere to the innovation drive, increase R\&D investment from both the government and enterprises, promote the improvement of the industry's technological level, enhance the ability of independent innovation, and gradually form a virtuous circle of "input $\rightarrow$ output $\rightarrow$ input".

(3) Strengthen the training of talents and consolidate the guarantee for industrial development. First, take colleges and universities as an essential channel for talent training, and encourage qualified colleges and universities to add computer and information technology-related majors. Based on the needs of the industry, build a compound curriculum system of "general + specialty + industry", and reserve applied talents with comprehensive capabilities, professional knowledge, and industry experience for the industry. Second, innovate the talent training mechanism, increase cooperation with international and domestic universities, scientific research institutions, and enterprises, jointly build various industrial talent training bases and training systems, and accelerate the training of intermediate and senior talents. Third, increase the intensity of talent introduction, focusing on introducing high-end international talents in the industry with experience in handling trade disputes, trade negotiations, patent layout, setting international standards, and optimizing industrial talents' structure.

\section{Conclusions}

The computer information service industry is closely related to the fourth industrial revolution and is at the core of the global value chain. It has become an essential engine for developing industries in various countries, and its scale is constantly expanding. Using mathematical models to predict its international competitiveness will help scientifically evaluate its development and accelerate the adaptation to the needs of the fourth industrial revolution. In this article, we combine Grey theory and BP neural network algorithm to propose a GM-BP neural network model for predicting the international competitiveness of computer information service industry and take China as an example to verify it. The research results show that the prediction model has minor errors and excellent simulation results, and the applicability and reliability of the model are reasonable. In order to improve the accuracy of the long-term prediction model, our future research should introduce more neural network algorithms, compare the simulation effects of different algorithms, and improve the fit and prediction effect of the model. In addition, more factors affecting the international competitiveness of the computer information service industry will be included, and the model will be continuously optimized.

Author Contributions: Writing-original draft preparation, X.X.; supervision, M.A.A.; writingreview and editing, U.A. and A.M. All authors have read and agreed to the published version of the manuscript. 
Funding: This work is supported by the Humanistic and Social Science Research Program of Chongqing Municipal Education Commission (Grant No. 20SKGH276) and the Scientific and Technological Research Program of Chongqing Municipal Education Commission (Grant No. KJQN202101902).

Institutional Review Board Statement: Not applicable.

Informed Consent Statement: Not applicable.

Data Availability Statement: The data presented in this study are available within the article.

Conflicts of Interest: The authors declare no conflict of interest.

\section{References}

1. Balassa, B. Trade liberalization and revealed comparative advantage. Manch. Sch. Econ. Soc. Stud. 1965, 33, 99-123. [CrossRef]

2. Porter, M.E. The Competitive Advantage of Nations; Free Press: New York, NY, USA, 1990.

3. Jensen, H.H.; Voigt, S.W.; Hayes, D.J. Measuring international competitiveness in the pork sector. Agribusiness 1995, 11, 169-177. [CrossRef]

4. Mortimore, M.; Leiva, R.Z. The international competitiveness of the Costa Rican clothing industry. Ann. N. Y. Acad. Sci. 1999, 877, 486-498.

5. Gallagher, P.; Schamel, G.; Shapouri, H.; Brubaker, H. The international competitiveness of the U.S. corn-ethanol industry: A comparison with sugar-ethanol processing in Brazil. Agribusiness 2006, 22, 109-134. [CrossRef]

6. Esterhuizen, D.; Rooyen, C.V. An inquiry into factors impacting on the competitiveness of the South African wine industry. Agrekon 2006, 45, 467-485. [CrossRef]

7. Asselt, H.V.; Biermann, F. European emissions trading and the international competitiveness of energy-intensive industries: A legal and political evaluation of possible supporting measures. Energy Policy 2007, 35, 497-506. [CrossRef]

8. Huang, M.Y.; Deng, X.H. An empirical analysis on the determinants of international competitiveness in China's financial services trade. World Econ. Study 2011, 7, 3-9.

9. Grimm, A. Trends in U.S. trade in information and communications technology (ICT) services and in ICT-enabled services. Surv. Curr. Bus. 2016, 5, 1-19.

10. Biryukova, O.V.; Matiukhina, A.I. ICT services trade in the BRICS countries: Special and common features. J. Knowl. Econ. 2018, 10, 80-97. [CrossRef]

11. Wang, F.L. A Comparative study on the competitiveness of Information technology-intensive service trade between China and ASEAN. J. Chongqing Jiaotong Univ. (Soc. Sci. Ed.) 2018, 18, 57-62.

12. Liang, R.; Liu, Z.Y. Comparative research of competitiveness and influence factors of computer and information service trade of South Korea, China, and Japan. J. Korea Soc. Comput. Inf. 2014, 19, 329-338.

13. Guo, Y.M. Research on the International Competitiveness of Telecommunication, Computer and Information Services Trade, and its Influencing Factors: Based on the Empirical Analysis of the G20; Beijing Foreign Studies University: Beijing, China, 2019.

14. Li, H.C.; Fan, S.J. An empirical study on the international competitiveness of China's ICT industry based on co-integration analysis. Sci. Technol. Manag. Res. 2015, 35, 109-113.

15. Nath, H.K.; Liu, L. Information and communications technology (ICT) and services trade. Inf. Econ. Policy 2017, 41, 81-87. [CrossRef]

16. Wang, L.Y.; Chen, G.G. A comparative study on the international competitiveness of China and India in computer and information services trade. Res. Financ. Theory 2017, 6, 47-54.

17. Zhang, F.; Xue, H.F. Will environmental regulation and real exchange rate affect the improvement of international competitiveness of manufacturing industry? Sci. Sci. Manag. Sci. Technol. 2016, 37, 68-82.

18. Tang, H.X.; Zhang, X.Z.; Wu, Y.; He, Z.C. Research on the development quality of China's manufacturing industry and the improvement of international competitiveness. China Soft Sci. 2019, 2, 128-142.

19. Zhao, X.X.; Yang, C. China's international trade pattern and import and export volume forecast of grass seeds. Grass Ind. Sci. 2020, 37, 1646-1655.

20. Jiang, B.; Xiong, T.L. Forecast of export demand based on artificial neural network and fuzzy system theory. J. Intell. Fuzzy Syst. 2020, 39, 1701-1709.

21. Li, S.H.; Zhang, Y.Q. Analysis on the international competitiveness of Russian forest products. J. Russ. 2021, 11, 105-126.

22. Wang, B.X.; Liu, Y. Based on gray BP neural network model of human resource demand forecasting method. J. Stat. Decis. 2018, $16,181-184$

23. Li, Y.H.; Yang, X.Y.; Liu, D.X. Industrial human resource demand prediction based on GDP-Bagging network model: A case study of strategic emerging industries in Shanxi province. Sci. Technol. Manag. Res. 2018, 38, 178-185.

24. Yuan, J.B.; Li, X. Highway passenger traffic forecast based on grey GM (1,3)-Markov chain model. Transp. Sci. Eng. 2011, 27, 68-72.

25. Fainshmidt, S.; Smith, A.; Judge, W.Q. National competitiveness and Porter's diamond model: The role of MNE penetration and governance quality. Glob. Strategy J. 2016, 6, 81-104. [CrossRef] 
26. Zhang, C.X. Research on competitiveness evaluation of regional cultural tourism industry based on diamond model. J. Manag. 2018, 15, 1781-1788.

27. Xu, Z.Y.; Zhang, M.; Ma, Y.Q. A study on the international competitiveness of China's service trade and its influencing factors from the perspective of the global value chain. Int. Trade 2018, 1, 60-66.

28. Lan, Q.X.; Dou, K. An empirical study on the international competitiveness of China's digital trade based on the "diamond model". Soc. Sci. 2019, 3, 44-54.

29. Sun, X.L. European Service trade competitiveness and its influencing factors: Based on Porter's diamond model. J. Southwest Univ. Natl. 2020, 41, 128-137.

30. Ma, R.; Luo, H.; Wang, H.W. Research on the evaluation index system and measurement of China's regional economic high-quality development. China Soft Sci. 2019, 7, 60-67.

31. Huang, P.; Zeng, S.L.; Long, Z. Research on the temporal and spatial evolution of industrialization quality and high-quality development path in the western region. China Popul. Resour. Environ. 2019, 29, 50-58.

32. Liu, B.; Long, R.Y.; Zhu, C.G.; Sun, X.X.; Pan, K.Y. Evaluation of the high-quality development level of marine economy in Jiangsu Province. Econ. Geogr. 2020, 40, 104-113.

33. Wang, W.; Wang, C.J. Evaluation of high-quality development in northeast China and its spatial characteristics. Geogr. Sci. 2020, 40, 1795-1802.

34. Brem, A.; Nylund, P.A.; Schuster, G. Innovation and de facto standardization: The influence of dominant design on innovative performance, radical innovation, and process innovation. Technovation 2016, 50, 79-88. [CrossRef]

35. Juan-Jose, A.; Bas, M.C.; Vicent, G.B.; Raul, R.-R.; María, J.V. An evaluation of the environmental factors for supply chain strategy decisions using grey systems and composite indicators. Appl. Math. Model. 2020, 79, 490-505.

36. Wu, X.Y.; Zhang, Y.J. China's digital economy and its international competitiveness. Sci. Res. Manag. 2020, 41, $250-258$.

37. Liu, Z.D.; Zhan, Q.Q.; Tian, G.L. Research review of factor analysis comprehensive evaluation. Stat. Decis. 2019, $19,68-73$.

38. Shen, Y.; Han, Y. A model for predicting the demand for technical skills and its test: Based on BP neural network perspective. Contemp. Vocat. Educ. 2020, 2, 72-78.

39. Xu, X.H. Research on the international competitiveness of Chinese wine industry: An analysis based on the perspective of trade performance evaluation. Price Theory Pract. 2020, 1, 171-174. 